UDC 323.2

Submitted: 24.09 .2020

LBC 66.3(2Poc), 1

Accepted: 22.01 .2021

\title{
INTEGRATION OF PUBLIC GOVERNMENT INSTITUTIONS IN THE PROCESS OF THE STATE SOCIAL POLICIES FORMATION IN THE SOUTH OF RUSSIA ${ }^{1}$
}

\author{
Sergey D. Gavrilov \\ Volgograd State University, Volgograd, Russian Federation \\ Diana K. Azizova \\ Volgograd State University, Volgograd, Russian Federation
}

\begin{abstract}
Introduction. The study is devoted to the analysis of modern integration processes in the context of the state social policy implementation, taking the specifics of the public policy space in the macroregional dimension into account. The research problem is to clarify the optimal predictive scenarios for the development of the integration of public government institutions in the decision-making process aimed at the formation of social policy in the South of Russia. Methodology and methods. The study was conducted in the context of two methodological foundations (structural functionalism as interpreted by T. Parsons and M. Olson's theory of collective action). The choice of methodological tools is due to the presence of two components in the object of analysis - the functional process of implementing social policy and the communicative nature of institutional integration. Quantitative content analysis is used to clarify the priorities of the socio-political development of the southern Russia regions. The sources and materials of the study were official documents (strategies for the socio-economic development of the southern Russia regions), reports on the implementation of state programs, as well as materials of state statistics of the Russian Federation. Analysis. The modern political and communicative environment in Russia is characterized by the public sphere transformation in the context of constitutional changes and modernization reforms. Social policy is presented as a product that addresses a fundamental function - the achievement of social welfare. Regionalization of Russia determines the direction and form of communications regarding the implementation of social policy. At the same time, in the southern Russia regions, a positive practice of integration interaction is recorded in the form of the adoption of a fundamentally new document "social code", which unites many social practices. Results. Based on the results of the study, it was revealed that the existing practices of regional integration are based on replicating the best practices in the South of Russia. The formation of state social policy in the macro-regional dimension is based on the implementation of federal target programs and state projects. At the same time, each of the regions has its own request for the formation of social policy priorities, which allows them to be segmented into two groups: regions with existing infrastructure for the development of the social sphere, as well as regions that systematize the best practices of social project management in order to form their own development infrastructure.
\end{abstract}

Key words: public authority, integration, state social policy, macro-regional development, South of Russia.

Citation. Gavrilov S.D., Azizova D.K. Integration of Public Government Institutions in the Process of the State Social Policies Formation in the South of Russia. Vestnik Volgogradskogo gosudarstvennogo universiteta. Seriya 4. Istoriya. Regionovedenie. Mezhdunarodnye otnosheniya [Science Journal of Volgograd State University. History. Area Studies. International Relations], 2021, vol. 26, no. 3, pp. 191-202. (in Russian). DOI: https://doi.org/ 10.15688/jvolsu4.2021.3.17 


\title{
ПРАКТИКИ ВЗАИМОДЕЙСТВИЯ ИНСТИТУТОВ ВЛАСТИ И ОБЩЕСТВА
}

УДК 323.2

Дата поступления статьи: 24.09.2020

ББК 66.3(2Poc), 1

Дата принятия статьи: 22.01.2021

\section{ИНТЕГРАЦИЯ ИНСТИТУТОВ ПУБЛИЧНОЙ ВЛАСТИ В ПРОЦЕССЕ ФОРМИРОВАНИЯ ГОСУДАРСТВЕННОЙ СОЦИАЛЬНОЙ ПОЛИТИКИ НА ЮГЕ РОССИИ ${ }^{1}$}

\author{
Сергей Дмитриевич Гаврилов \\ Волгоградский государственный университет, г. Волгоград, Российская Федерация \\ Диана Качабековна Азизова \\ Волгоградский государственный университет, г. Волгоград, Российская Федерация
}

\begin{abstract}
Аннотация. Введение. Исследование посвящено анализу современных интеграционных процессов в контексте реализации государственной социальной политики с учетом специфики пространства публичной политики в макрорегиональном измерении. Исследовательская проблема заключается в уточнении оптимальных прогнозных сценариев развития интеграции институтов публичной власти в процессе принятия решений, направленных на формирование социальной политики на Юге России. Методология и методы. Исследование проведено в контексте двух методологических оснований (структурный функционализм в интерпретации Т. Парсонса и теория коллективного действия М. Олсона). Выбор методологического инструментария обусловлен наличием двух компонентов в объекте анализа - функционального процесса реализации социальной политики и коммуникативной природы институциональной интеграции. Количественный контент-анализ использован с целью уточнения приоритетов социально-политического развития регионов Юга России. В качестве источников и материалов исследования выступили официальные документы (стратегии социально-экономического развития регионов ЮФО и СКФО), отчеты о реализации государственных программ, а также материалы государственной статистики РФ. Анализ. Современная политико-коммуникативная среда в России характеризуется трансформацией публичной сферы в контексте конституционных изменений и модернизационных преобразований. Социальная политика представляется как продукт, направленный на решение основополагающей функции государства - достижения социального блага. Регионализация России определяет направленность и форму коммуникаций по поводу реализации социальной политики. Вместе с тем в регионах Юга России фиксируется позитивная практика интеграционного взаимодействия в форме принятия принципиально нового документа - Социального кодекса, который объединяет многие социальные практики. Результаты. По итогам проведенного исследования выявлено, что существующие практики интеграции регионов основаны на тиражировании лучших практик на пространстве Юга России. Формирование государственной социальной политики в макрорегиональном измерении основано на реализации федеральных целевых программ и государственных проектов. Вместе с тем каждый из регионов обладает собственным запросом на формирование приоритетов социальной политики, что позволяет сегментировать их по двум группам: регионы с имеющейся инфраструктурой для развития социальной сферы, а также регионы, систематизирующие лучшие практики управления социальными проектами с целью формирования собственной инфраструктуры развития. Вклад авторов. С.Д. Гаврилов провел анализ тенденций макрорегионального развития Юга России с позиции институционального дизайна публичной власти, уточнил вариативность интеграционных стратегий по формированию социальной политики, а также интерпретировал результаты контент-анализа стратегий социально-экономического развития регионов. Д.К. Азизова систематизировала опыт регионов по формированию государственной социальной политики, выявила направленность дальнейшего развития Юга России как политикокоммуникативного пространства по достижению единых требований для реализации социальных благ, а также выделила приоритеты развития публичной политики субъектов Юга России с реальными практиками реализации государственных программ и региональных проектов.
\end{abstract}

Ключевые слова: публичная власть, интеграция, государственная социальная политика, макрорегиональное развитие, Юг России.

Цитирование. Гаврилов С. Д., Азизова Д. К. Интеграция институтов публичной власти в процессе формирования государственной социальной политики на Юге России // Вестник Волгоградского государственного университета. Серия 4, История. Регионоведение. Международные отношения. - 2021. - Т. 26, № 3. - C. 191-202. - DOI: https://doi.org/10.15688/jvolsu4.2021.3.17 
Введение. Сфера публичного в современной российской политике представляет собой многомерное пространство интеракций между акторами политического процесса с использованием различных инструментов коммуникации для формирования единой «повестки дня» или стратегии развития по линии «личность - общество - государство». В демократических обществах публичная политика есть пространство открытой коммуникации, гласности и согласованности действий между всеми участниками общественно-политического процесса по поводу реализации основных направлений государственной политики. Специфика развития системы административно-политического управления в России свидетельствует как о продолжении конструирования строгой «вертикали власти», так и о регионализации политики, выражающейся в параллельном взаимодействии по линиям «центр регионы», «центр - макрорегионы», «центр макрорегионы - регионы» в зависимости от целей, задач и приоритетов государственной политики, а в особенности от ее социального направления. В указанном контексте для России и ее регионов необходимо проанализировать феномен «публичной власти» с учетом формирования контуров «новой политической системы», обозначенных в поправке к Конституции РФ 2020 года. Проблемный характер механизмов и практик взаимодействия институтов публичной власти в плоскости государственной социальной политики, обусловленный персональными политическими интересами в реализуемой деятельности и вынужденными коллективными действиями, определяет необходимость политического анализа, прогнозных сценариев развития их потенциальной способности к интеграции в контексте участия в процессе принятия решений на Юге России.

Методология и методы исследования. Публичная политика в целом и публичная власть в частности есть общественнополитические феномены, исследование которых обусловлено развитием демократических институтов, представительного характера власти, а также признанием гражданского общества как полноправного участника социальных отношений и политического процесса. В теории политики сложились несколько ключевых оснований к исследованию публичной полити- ки в контексте формирования отдельных направлений и действий государства: 1) публичная политика как условие управления социальными процессами (Х. Арендт, Ю. Хабермас); 2) публичная политика как целевой курс действия, производимый и определяемый через деятельность правительства и чиновников (Дж. Андерсон, Т. Дай); 3) публичная политика как поле взаимодействия гражданского общества и государства (В.В. Волков, А.А. Галкин, Ю.А. Красин, В.А. Михеев, Ю.М. Розанова, А.Ю. Сунгуров и др.).

Сложность исследовательской задачи определяет необходимость использования некоторых методологических оснований: структурно-функционального подхода Т. Парсонса [8], который необходим для осмысления социальной политики как элемента государственной политики, обладающей специфической функцией достижения социального благосостояния; теории коллективного действия в интерпретации М. Олсона [6], представляющей собой логичный синтез как психологических, так и институциональных оснований политической коммуникации, в соответствии с которой интеграция выступает как коллективное благо. В качестве конкретных методов исследования используются: кейс-стади, необходимые для осмысления существующего опыта формирования приоритетов социальной политики и анализа вариативности интеграционных процессов институтов публичной власти, а также количественный контент-анализ с целью выявления приоритетных направлений развития публичного пространства в контексте социальноэкономических показателей.

Анализ. Логика анализа публичного пространства в социально-политических исследованиях детерминирует понимание данной категории как коммуникативного поля субъектов политики, имеющего как абстрактные, так и вполне реальные границы. При этом пространством публичности могут выступать как средства массовой информации (газеты, интернет, телевидение, блогосфера), так и абстрактные пространства, предполагающие диалоговое общение масс и социальных групп, отдельных субъектов политического процесса (митинги, дебаты, «прямые линии» и т. п.). Значимость публичного определяется не только необходимостью коммуникации в полити- 


\section{ПРАКТИКИ ВЗАИМОДЕЙСТВИЯ ИНСТИТУТОВ ВЛАСТИ И ОБЩЕСТВА}

ке, но и показывает наличие самоорганизованности участников социально-политических действий, ведь «социум в действительности есть форма, в какой сам по себе процесс жизни публично институировал и организовал себя» [15, с. 101].

В России публичное пространство политики используется скорее в условиях необходимости институционализации сферы гражданской самоорганизации путем коллаборации действий власти и общества по поводу реализации отдельных направлений государственной политики. Вместе с тем реакционный характер российской власти может провоцировать конфронтацию административной системы и населения, что «препятствует формированию чувства гражданственности, развитию политико-правовой культуры и легитимному восприятию населением значимости административно-государственного управления» $[4$, с. 59]. В связи с этим необходимость публичной политической коммуникации между властью и институтами гражданского общества объективируется интеракциями по поводу социальной политики, которая представляется наиболее выгодной для обеих сторон. Указанное обстоятельство обусловлено тем, что для государства социальная функция есть фундаментальная основа существования института и попытка осуществления социальноэкономического контроля над различными группами населения [2], а для граждан улучшение социального благосостояния, качества и уровня жизни имеет приоритетное значение.

Политико-коммуникативное пространство в России формировалось в условиях форматирования государства в 1990-х гг., а также с попыткой найти новые механизмы, инструменты, мотивы диалога власти и общества, что выражается в основополагающем принципе реализации публичной «коммуникации через механизм информационного повода» [14, c. 27]. Российская политическая действительность основана на многоуровневой системе коммуникации федерального, макрорегионального, регионального взаимодействия различных институтов власти и гражданского общества. Таким образом, среда политической коммуникации в России представляется сложной структурированной системой интеракций субъектов политического процесса, в которой формируется идея «общего блага», обозначенная через наличие информационного повода.

В политической науке принято разграничивать понятия «государственная власть» и «публичная власть», основываясь на разнице субъектного состава. Так, государственную власть могут реализовывать только органы государственной власти, а публичную власть осуществляет как государство, так и негосударственные акторы. Такая логика была уместна и для познания российского политического процесса вплоть до вступления в силу поправки к Конституции РФ 2020 г., которая закрепила понятие «публичная власть» в нормативном поле, а также конституционное урегулирование основ ее организации. Согласно ч. 2 ст. 80 Конституции РФ, Президент РФ обеспечивает единство системы публичной власти и взаимодействие входящих в нее органов, а ч. 2 ст. 132 свидетельствует о том, что «органы местного самоуправления и органы государственной власти входят в единую систему публичной власти в Российской Федерации и осуществляют взаимодействие для наиболее эффективного решения задач в интересах населения, проживающего на соответствующей территории» [3]. Однако содержание категории «публичная власть» в Основном законе РФ осталось нераскрытым. Более того, концепт «единая система публичной власти» сосредоточивает исследовательское внимание на интерпретации сути интеграционных процессов в контексте реализации власти.

Основной сферой взаимодействия социума и государства является сфера социальной политики. Представители органов государственной власти для поддержания своей легитимности занимаются решением острых социальных проблем, повышением уровня и качества жизни общества. Для этого необходимо выработать оптимальную модель реализации социальной политики, которая будет учитывать все нюансы: экономическую ситуацию, специфику геополитического положения региона, социокультурные и социально-экономические факторы его развития, уровень участия гражданского общества в решениях социально-экономических, политических и социокультурных задач. Организация публичного политического пространства для диалога власти и общества пред- 
ставляется наиболее важным условием для реализации социальной политики.

Социальная политика определяется как организационно оформленные, нормативно закрепленные и регулярно воспроизводимые институциональные практики установления параметров предоставления социальных благ и услуг отдельным категориям населения в соответствии с принципами адресности и нуждаемости. Основополагающим является процесс согласования и принятия взаимных обязательств государственными и негосударственными институтами социальной политики с учетом имеющихся финансовых, экономических, организационно-управленческих ресурсов, а также совокупности используемых механизмов и инструментов обеспечения качества жизни населения. Таким образом, совершенно справедливо, что социальная политика детерминируется «достижением социального мира в интересах общественного блага» $[11$, с. 324$]$.

В эпоху глобализации абсолютно все политические субъекты становятся взаимозависимыми. Такая же ситуация складывается и в регионах нашей страны с учетом развития взаимоотношений по линии «центр - макрорегионы - регионы». Взаимодействуя между собой, они создают новые инструменты реализации социальной политики с учетом современных технологий, максимально отвечающие актуальным запросам общества. Например, одним из важнейших кейсов, демонстрирующих интеграцию институтов публичной власти, является Социальный кодекс, который был принят сразу в нескольких субъектах Юга России (прежде всего в Астраханской и Волгоградской областях). Указанный документ объединил и систематизировал сотни региональных законов и нормативных актов, установил новые меры социальной помощи и поддержки, порядок их предоставления. Кодекс уточнил критерии адресности и нуждаемости, что в разы увеличило эффективность предоставления мер социальной помощи. Этот важнейший шаг изменил методы оказания социальной помощи в целом. Благоприятный опыт принятия Социального кодекса стал отправной точкой для его разработки в других регионах Юга России. Так, Президент России В.В. Путин предложил тиражировать опыт по созданию Социального ко- декса в Волгоградской области в других субъектах РФ [1].

Основным механизмом реализации государственной социальной политики также являются государственные программы. Важно, что целевые государственные программы учитывают целесообразность реализации той или иной модели социальной политики. На сегодняшний день в перечне реализуемых государственных программ предусмотрены 44 программы. Все проекты сгруппированы в 5 программных блоков. Один из блоков «Новое качество жизни» предполагает повышение доступности услуг образования и здравоохранения, высокий уровень обеспеченности населения жильем, улучшение качества и уровня жизни населения в целом. Масштабная долгосрочная госпрограмма «Социальная поддержка граждан» из данного блока, реализуемая Министерством труда и социальной защиты Российской Федерации с 2013 г., включает в себя подпрограммы и федеральные целевые программы: «Обеспечение мер социальной поддержки отдельных категорий граждан», «Модернизация и развитие социального обслуживания населения», «Обеспечение государственной поддержки семей, имеющих детей», «Повышение эффективности государственной поддержки социально ориентированных некоммерческих организаций», «Старшее поколение», «Обеспечение условий реализации государственной программы Российской Федерации “Социальная поддержка граждан”» [13]. Первый этап госпрограммы реализуется с 1 января 2013 г. по 31 декабря 2024 года.

В рамках данной госпрограммы реализуются мероприятия по развитию конкурентного рынка в сфере социального обслуживания граждан, в том числе по развитию партнерства между государством и негосударственными организациями. Налаживание политико-коммуникативного диалога между государством и третьим сектором в рамках программы «Повышение эффективности государственной поддержки социально ориентированных некоммерческих организаций» оказало позитивное влияние на государственно-частное партнерство. Так, к 2019 г. количество негосударственных организаций, оказывающих услуги социального обслуживания, воз- 


\section{ПРАКТИКИ ВЗАИМОДЕЙСТВИЯ ИНСТИТУТОВ ВЛАСТИ И ОБЩЕСТВА}

росло до 1 300, 900 из которых являются социально ориентированными некоммерческими организациями. В этом ключе также осуществлялись меры по повышению заработной платы социальных работников. В 2019 г. средняя заработная плата составила 35180 руб., что на $6,2 \%$ больше предыдущих показателей. Эти плановые показатели достигнуты во всех регионах Юга России.

Система поддержки семей, воспитывающих детей, также получила развитие. Установлена ежемесячная выплата в связи с рождением (усыновлением) первого ребенка, составляющая 11177 руб. в среднем по стране. Средний размер единовременной выплаты семьям при рождении первого ребенка составил 30971 руб. в регионах Юга России. Региональный материнский (семейный) капитал при рождении второго ребенка в 2019 г. установлен в размере 135900 рублей. Также продолжаются выплаты детских пособий. В рамках реализации программы «Старшее поколение» во всех субъектах Юга России приобретены средства передвижения для транспортировки лиц пенсионного возраста, проживающих в отдаленных поселениях, в медицинские учреждения. Благодаря данному мероприятию сотни тысяч граждан преклонного возраста своевременно получили медицинскую помощь. Несмотря на то что первый этап реализации данной госпрограммы еще не завершен, промежуточные результаты указывают на эффективность принимаемых мер.

Параллельно на Юге России реализуется Стратегия социально-экономического развития Южного федерального округа на период до 2020 г. [10], Стратегия социально-экономического развития Северо-Кавказского федерального округа до 2025 года [9]. Перечисленные в документах мероприятия уже сегодня дали высокие промежуточные результаты в регионах Юга России (в частности, по ЮФО). Так, например, в Республике Адыгея реализуется высокий социокультурный потенциал региона, который связан, прежде всего, с благоприятной возрастной структурой населения, этнокультурным наследием и наличием туристического потенциала. Приоритетом развития социальной сферы Республики Калмыкия является создание благоприятных городских условий жизни в административных единицах для возможности получения населением необходимых социальных благ. Краснодарский край также активно реализует мероприятия данной госпрограммы, в частности - в жилищном строительстве. Астраханская, Ростовская и Волгоградская области имеют схожие перспективы развития социальной политики. Выгодное географическое положение этих регионов способствует налаживанию международных транспортных коридоров. Однако в указанных областях наблюдается сложная ситуация с экологическим загрязнением, и существенное количество мероприятий проводится именно в этом направлении. Особое внимание уделяется также развитию медицинской промышленности, туристско-рекреационного комплекса. В последние годы Волгоград набрал высокие темпы развития социальной политики, в частности в 2019 г. став участником пилотного проекта системы долговременного ухода за инвалидами и пожилыми людьми [12].

Вместе с тем наиболее проблемные аспекты достижения указанных в документах показателей совместного развития регионов Юга России (в том числе Северо-Кавказского федерального округа) связаны прежде всего со значительными межрегиональными и межмуниципальными различиями по степени экономической активности и уровню жизни населения. Так, согласно данным Федеральной службы государственной статистики (https://rosstat.gov.ru), положение регионов ЮФО и СКФО по уровню жизни крайне неоднородно: разброс между доходами составляет 17686 руб., между расходами 21860 руб. (см. рисунок). Данный показатель является особенно значимым при реализации социальной политики, а трудности интеграционного развития связаны прежде всего с тем, что показатель уровня доходов составляет $154,22 \%$ (расходов - 190,62 \%) от величины прожиточного минимума на душу населения в целом по Российской Федерации за II квартал 2020 года.

При осмыслении имеющихся региональных приоритетов развития наиболее целесообразно проанализировать стратегии социально-экономического развития, которые приняты во всех субъектах ЮФО и СКФО, на основе метода количественного контент-анали- 


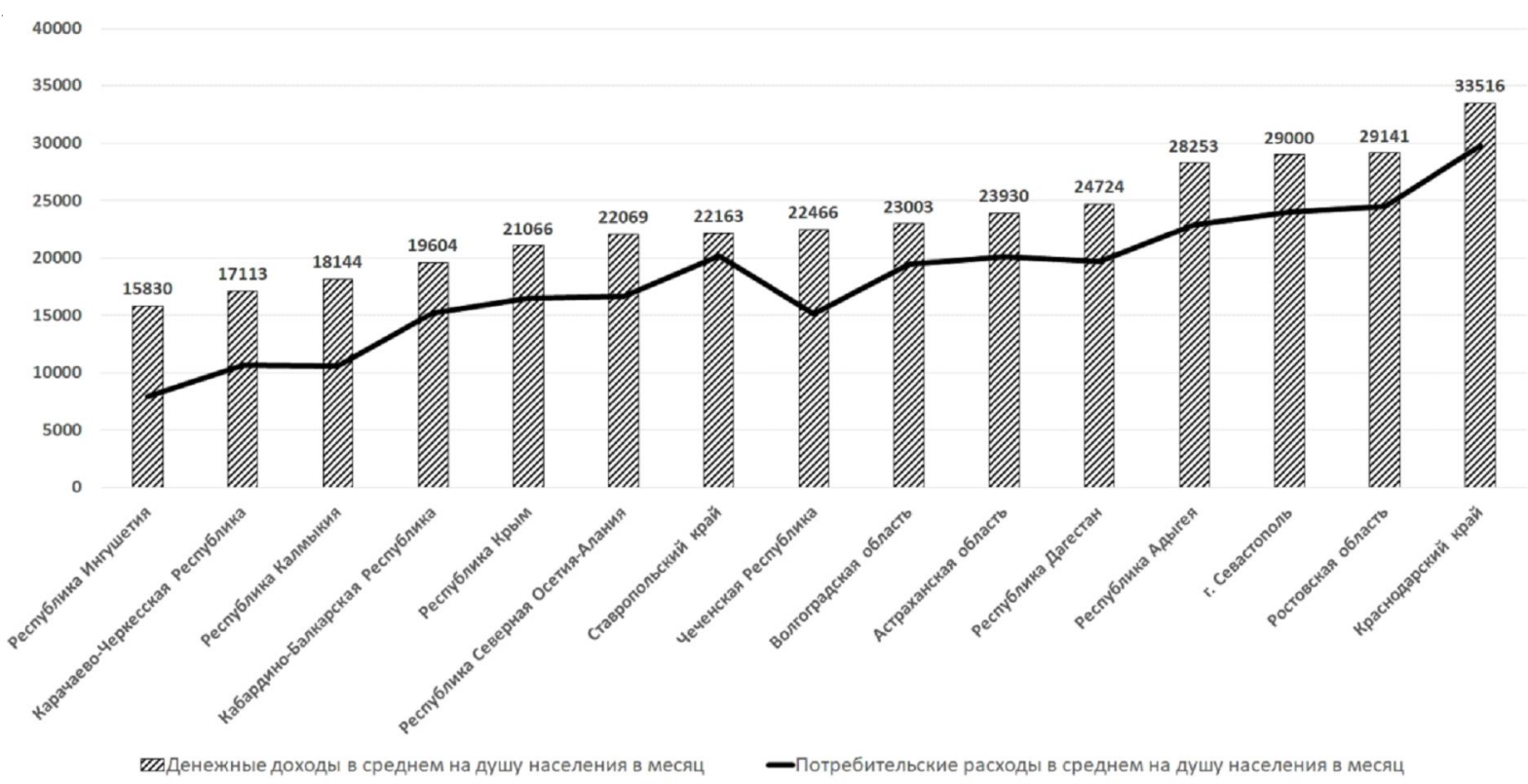

Денежные доходы и потребительские расходы в регионах ЮФО и СКФО по состоянию на январь - сентябрь 2020 г.

(по материалам Федеральной службы государственной статистики)

Cash income and consumer spending in the regions

of the Southern Federal District and the North Caucasus Federal District as of January - September 2020

(based on the materials of the Federal State Statistics Service)

за. Единицами анализа выступили основные категории приоритетов социально-экономического развития по сферам жизнедеятельности. Полученные результаты (преобразованы с помощью линейной нормировки униполярных данных) свидетельствуют о различной направленности приоритетов регионального развития. Так, например, для регионов ЮФО наиболее приоритетными направлениями развития в среднем представляются образование, здравоохранение, строительство, демография, промышленность; в СКФО - экономика, предпринимательство, промышленность, транспорт, культура (см. табл. 1-2).

Таким образом, разность потенциала развития регионов Юга России дает возможность структурировать их по двум группам: регионы с развитой инфраструктурой, которые нацелены на проектирование новых социальных практик (Республика Калмыкия, Астраханская область, Волгоградская область, Кабардино-Балкарская Республика, Карачаево-Черкесская Республика, Ставропольский край, Краснодарский край); регионы, для которых первоочередная задача - создание фундаментальной базы для систематизации имеющихся практик со- циального развития (Республика Адыгея, Чеченская Республика, Ростовская область, Севастополь, Республика Крым, Республика Ингушетия, Республика Дагестан, Республика Северная Осетия - Алания).

Стоит также отметить, что результат интеграции институтов публичной власти на Юге России представляется не как «взаимное поглощение» функционала друг друга, а скорее, как обмен опытом, лучшими практиками с целью формирования единой среды социального благополучия на Юге России. Указанное обстоятельство представляется, с одной стороны, позитивной практикой, так как обусловливает логику «равного участия» различных институтов публичной власти в процессе реализации социальной политики как в пространстве субъектов РФ, так и на Юге России в целом; с другой стороны - является препятствием динамичного развития макрорегиона. Таким образом, представляется важным сформулировать два сценария (стратегии) развития интеграционных процессов на Юге России по вопросу формирования социальной политики с целью предложения различным участникам общественно-политического процесса. 
Таблица 1. Направления приоритетов социально-экономического развития регионов Южного федерального округа

Table 1. Directions of the socio-economic development priorities in the regions of the Southern Federal District

\begin{tabular}{|l|c|c|c|c|c|c|c|c|}
\hline & $\begin{array}{c}\text { Астра- } \\
\text { ханская } \\
\text { область }\end{array}$ & $\begin{array}{c}\text { Волго- } \\
\text { градская } \\
\text { область }\end{array}$ & $\begin{array}{c}\text { Красно- } \\
\text { дарский } \\
\text { край }\end{array}$ & $\begin{array}{c}\text { Респуб- } \\
\text { лика } \\
\text { Адыгея }\end{array}$ & $\begin{array}{c}\text { Респуб- } \\
\text { лика } \\
\text { Калмы- } \\
\text { кия }\end{array}$ & $\begin{array}{c}\text { Респуб- } \\
\text { лика } \\
\text { Крым }\end{array}$ & $\begin{array}{c}\text { Ростов- } \\
\text { ская об- } \\
\text { ласть }\end{array}$ & $\begin{array}{c}\text { Севасто- } \\
\text { поль }\end{array}$ \\
\hline Демография & 0,1515 & 1 & 0,0909 & 0 & 0,4242 & 0,6364 & 0,0606 & 0,1212 \\
\hline Жилье & 0,2157 & 1 & 0,5196 & 0 & 0,1863 & 0,0392 & 0,0294 & 0,2059 \\
\hline $\begin{array}{l}\text { Здравоохране- } \\
\text { ние }\end{array}$ & 0,4722 & 0,5278 & 1 & 0 & 0,8056 & 0,1389 & 0,0278 & 0,2778 \\
\hline Культура & 0,7664 & 0,2993 & 1 & 0,0073 & 0 & 0,0146 & 0,0657 & 0,1898 \\
\hline Миграция & 0,2 & 1 & 0,4857 & 0 & 0 & 0,4857 & 0,0571 & 0,1429 \\
\hline Наука & 0,4586 & 0,4812 & 1 & 0,0075 & 0 & 0,0526 & 0,0301 & 0,0075 \\
\hline Образование & 0,6027 & 0,363 & 0,9863 & 0 & 1 & 0,0274 & 0,1438 & 0,226 \\
\hline $\begin{array}{l}\text { Предпринима- } \\
\text { тельство }\end{array}$ & 0,44 & 0,14 & 1 & 0,0333 & 0,3267 & 0,0267 & 0,04 & 0 \\
\hline $\begin{array}{l}\text { Промышлен- } \\
\text { ность }\end{array}$ & 0,4857 & 0,6381 & 1 & 0 & 0,1476 & 0,0476 & 0,0667 & 0,0762 \\
\hline Строительство & 0,6563 & 1 & 0,8125 & 0 & 0 & 0,0391 & 0,0234 & 0,1016 \\
\hline Транспорт & 0,5565 & 0,6569 & 1 & 0,0167 & 0 & 0,0879 & 0,0084 & 0,1339 \\
\hline $\begin{array}{l}\text { Цифровая } \\
\text { среда }\end{array}$ & 0 & 0 & 0 & 0 & 1 & 0,0769 & 0,4615 & 0,0769 \\
\hline $\begin{array}{l}\text { Цифровая } \\
\text { Экономика }\end{array}$ & 0 & 0 & 0,1538 & 0 & 1 & 0,0769 & 0 & 0 \\
\hline Экология & 0,3551 & 0,757 & 1 & 0 & 0 & 0,028 & 0,0374 & 0,0093 \\
\hline Экономика & 0,6377 & 0,4954 & 1 & 0,0222 & 0 & 0,0684 & 0,0573 & 0,0481 \\
\hline
\end{tabular}

Таблица 2. Направления приоритетов социально-экономического развития регионов Северо-Кавказского федерального округа

Table 2. Directions of the socio-economic development priorities in the regions of the North Caucasus Federal District

\begin{tabular}{|l|c|c|c|c|c|c|c|}
\hline & $\begin{array}{c}\text { Кабардино- } \\
\text { Балкар- } \\
\text { ская Рес- } \\
\text { публика }\end{array}$ & $\begin{array}{c}\text { Карачаево- } \\
\text { Черкесская } \\
\text { Республика }\end{array}$ & $\begin{array}{c}\text { Республика } \\
\text { Дагестан }\end{array}$ & $\begin{array}{c}\text { Республика } \\
\text { Ингушетия }\end{array}$ & $\begin{array}{c}\text { Республика } \\
\text { Северная } \\
\text { Осетия - } \\
\text { Алания }\end{array}$ & $\begin{array}{c}\text { Ставро- } \\
\text { польский } \\
\text { край }\end{array}$ & $\begin{array}{c}\text { Чеченская } \\
\text { Республика }\end{array}$ \\
\hline Демография & 0,4 & 0,5 & 0,35 & 0,2 & 0,25 & 1 & 0 \\
\hline Жиле & 0,4884 & 1 & 0,0930 & 0,1977 & 0 & 0,2442 & 0 \\
\hline $\begin{array}{l}\text { Здравоохра- } \\
\text { нение }\end{array}$ & 0,1864 & 0,7797 & 0,1695 & 0,4237 & 0,1695 & 1 & 0 \\
\hline Культура & 0,5794 & 1 & 0,1032 & 0,2063 & 0,1190 & 1 & 0 \\
\hline Миграция & 0,1569 & 0,1176 & 0,0784 & 0 & 0 & 1 & 0 \\
\hline Наука & 1 & 0,5273 & 0,0909 & 0,0182 & 0,1455 & 0,4909 & 0 \\
\hline Образование & 0,1209 & 0,1976 & 0,0560 & 0,0059 & 0,1239 & 1 & 0 \\
\hline $\begin{array}{l}\text { Предприни- } \\
\text { мательство }\end{array}$ & 1 & 0,5119 & 0,1667 & 0,1548 & 0,6548 & 0,7262 & 0 \\
\hline $\begin{array}{l}\text { Промышлен- } \\
\text { ность }\end{array}$ & 0,5794 & 0,9048 & 0,1746 & 0 & 0,3492 & 1 & 0,1825 \\
\hline Строительство & 0,4498 & 1 & 0,0431 & 0,2153 & 0,2105 & 0,4354 & 0 \\
\hline Транспорт & 1 & 0,7921 & 0,2277 & 0,2376 & 0,2376 & 0,5545 & 0 \\
\hline $\begin{array}{l}\text { Цифровая } \\
\text { среда }\end{array}$ & 0 & 0 & 1 & 0,5 & 0,5 & 0,5 & 0 \\
\hline $\begin{array}{l}\text { Цифровая } \\
\text { экономика }\end{array}$ & 1 & 0 & 0,3333 & 0,1667 & 0 & 0,6667 & 0 \\
\hline Экология & 0,6731 & 1 & 0,0192 & 0,1538 & 0,0192 & 0,1731 & 0 \\
\hline Экономика & 1 & 0,9529 & 0,2118 & 0,0059 & 0,8412 & 0,5706 & 0 \\
\hline
\end{tabular}


Сценарий 1 - «взаимное стимулирование». Данный подход подразумевает перекрестное участие институтов публичной власти в реализации приоритетов социальной политики между регионами Юга России; постепенную реализацию задач стратегий социальноэкономического развития ЮФО и СКФО, нахождение смежных приоритетов и взаимные коллаборации. Такая стратегия наиболее ресурсозатратная и ведет к необходимости постоянного контроля над капиталами, необходимыми для формирования социальной политики. Данный подход опирается на продолжение опыта тиражирования Социального кодекса. Риски реализации указанного сценария связаны с тем, что регионы Юга России имеют различный потенциал развития и институты региональной публичной власти осознают «ограниченность возможностей планового подхода к разрешению современных проблемных вопросов жизнедеятельности населения на территории региона» [7, с. 298]. Отметим, что данный сценарий наиболее выгоден институтам гражданского общества, которые ставят своей целью мониторинг деятельности органов власти по достижению оптимальной социальной среды, а также использование лучших инструментов, технологий по преобразованию социума.

Сценарий 2 - «реакционное участие». Данный подход направлен на позицию невмешательства институтов публичной власти одного региона в политику другого до тех пор, пока нет в этом необходимости (по принципу «адресной помощи»). Вместе с этим социальное партнерство различных институтов выступает не только на межрегиональном уровне, но и на внутрирегиональном. Указанная стратегия не лишена недостатков, но является усредненным вариантом в условиях дефицитов бюджетов регионов и кризисов. Реализация указанного сценария сопряжена с опытом интеграции Республики Крым и города Севастополь в общее политико-коммуникативное пространство Юга России, обусловленное «институционализацией новой гражданской и государственной идентичности на основе единого исторического прошлого и сплава культур, традиций русских, украинцев, крымских татар (все они представляют многичисленных жителей Крыма) и граждан многонациональ- ной большой России» [5, с. 314-315]. Иными словами, до тех пор, пока существовал Крымский федеральный округ, в интеграции новых субъектов РФ в коммуникативное пространство Юга России не было необходимости. Среди рисков реализации указанной стратегии справедливо указать отсутствие комплексного подхода к социально-политическому и социально-экономическому развитию макрорегиона. Выбор оптимальной стратегии зависит как от общефедеральной повестки развития социальной политики, так и от неконвенционального договора между регионами Юга России.

Результаты. Результат проведенного исследования позволяет обозначить следующие выводы. Во-первых, итогом реализации современной социальной политики на Юге России в соответствии с принципами адресности и нуждаемости является установление партнерских отношений между государственными и негосударственными структурами; завершение разработки и принятие региональных программ социальной направленности в сфере здравоохранения, содействия занятости и охраны труда. Население в целом положительно оценивает реализацию данных программ, а также обеспечение нуждающихся доступным и комфортным жильем. Слаженная работа на всех уровнях власти, интеграция механизмов и инструментов в процессе реализации социальной политики на Юге России дает возможность оценивать ее состояние как стабильное. Дальнейшее улучшение качества социальной политики следует связывать с усилением адресности социальных проектов и совершенствованием процедур определения нуждаемости; внедрением новых механизмов оказания помощи и заключения социальных контрактов; совершенствованием информационных и телекоммуникационных технологий информирования граждан об изменениях в области предоставления государственных социальных услуг.

Во-вторых, существующие интеграционные процессы Юга России фиксируются в контексте формирования "общего блага» внутрирегионального развития в первую очередь, а затем - макрорегионального развития. Указанное обстоятельство обусловливает поиск нового подхода к анализу формиро- 


\section{ПРАКТИКИ ВЗАИМОДЕЙСТВИЯ ИНСТИТУТОВ ВЛАСТИ И ОБЩЕСТВА}

вания социальной политики как направления реализации власти, необходимого для стабильного функционирования множества общественных процессов. Предложенные сценарии развития опираются на существующие тенденции и противоречия регионализации России, а также на опыт интеграционного развития макрорегиона Юг России. Любая из стратегий предопределяет осуществление институтами публичной политики (гражданского общества) коллабораций как интеграционного механизма при реализации социальной политики. Отметим, что в указанном контексте имеется сложившаяся практика, которая рекомендуется к пролонгации институтам гражданской самоорганизации межрегиональных конференций «Социальные инвестиции юга России: лучшие практики управления в некоммерческом секторе», проводимая при поддержке Фонда президентских грантов. Вместе с тем каждый из подходов не исключает рисков развития сферы публичного пространства, но определяет приоритеты функционирования институтов в общей логике макрорегиона.

\section{ПРИМЕЧАНИЕ}

${ }^{1}$ Исследование выполнено при финансовой поддержке РФФИ и Администрации Волгоградской области в рамках научного проекта № 19-411340006 р_а «Социально-политическое проектирование публичного пространства и системы массовой коммуникации в регионах РФ (на примере Волгоградской области)»; а также при финансовой поддержке РФФИ и ЭИСИ в рамках научного проекта №20-011-31676.

The reported study was funded by RFBR and Volgograd Region Administration in the framework of research project no. 19-411-340006 p a "Socio-Political Design of Public Space and Mass Communication System in the Regions of the Russian Federation (The Example of the Volgograd Region)"; Funding: The reported study was funded by RFBR and EISR, project number 20-011-31676.

\section{СПИСОК ЛИТЕРАТУРЫ}

1. Владимир Путин поручил изучить опыт Волгоградской области по созданию Социального кодекса. - Электрон. текстовые дан. - Режим доступа: https://www.volgograd.ru/gubernator/ tekush/183141/ (дата обращения: 12.09.2020). - Загл. с экрана.

2. Григорьева, И. А. Социальная политика: основные понятия / И. А. Григорьева // Журнал исследований социальной политики. - 2003. - Т. 1, № 1. - Электрон. текстовые дан. - Режим доступа: https://cyberleninka.ru/article/n/ sotsialnaya-politikaosnovnye-ponyatiya (дата обращения: 10.09.2020). Загл. с экрана.

3. Конституция Российской Федерации : [принята всенародным голосованием 12.12.1993 с изменениями, одобренными в ходе общерос. голосования 01.07.2020]. - Электрон. текстовые дан. - Режим доступа: http://kremlin.ru/acts/constitution (дата обращения: 14.09.2020). - Загл. с экрана.

4. Морозов, С. И. Коммуникативные технологии легитимации региональных органов исполнительной власти в Волгоградской области / С. И. Морозов, Т. В. Порошина // Известия Тульского государственного университета. Гуманитарные науки. - 2017. - № 1. - С. 55-61.

5. Морозов, С. И. Республика Крым, Севастополь и Волгоградская область: политические стратегии сотрудничества / С. И. Морозов, С. А. Панкратов // История и современное развитие Причерноморья в контексте формирования патриотизма и укрепления ценностей российской цивилизации : материалы Междунар. науч.-практ. конф. / отв. ред.: А. В. Баранов, В. В. Касьянов. - Новороссийск : Кубан. гос. ун-т, 2018. - С. 313-316.

6. Олсон, М. Логика коллективных действий. Общественные блага и теория групп : пер. с англ. / М. Олсон. - М. : ФЭИ, 1995. - 174 с.

7. Панкратов, С. А. Социально-политическое проектирование публичного пространства Волгоградской области / С. А. Панкратов // Траектории политического развития России: институты, проекты, акторы : материалы Всерос. науч. конф. РАПН с междунар. участием. - М. : Моск. пед. гос. ун-т, 2019. - C. 297-298.

8. Парсонс, Т. Социальная система : пер. с англ. / Т. Парсонс. - М. : Академ. проект, 2018. - 530 с.

9. Распоряжение Правительства РФ от 06.09.2010 № 1485-р (ред. от 24.06.2020) «Об угверждении Стратегии социально-экономического развития Северо-Кавказского федерального округа до 2025 года». - Электрон. текстовые дан. - Режим доступа: http:// www.consultant.ru/document/cons_doc_LAW_105643/ 517741733b081df06def6b33102ee 7434 eda031 c/ (дата обращения: 13.09.2020). - Загл. с экрана.

10. Распоряжение Правительства РФ от 5 сентября 2011 г. № 1538-р «О Стратегии социально-экономического развития Южного федерального округа на период до 2020 г.». - Электрон. текстовые дан. - Режим доступа: http://docs.cntd.ru/document/902301126 (дата обращения: 13.09.2020). - Загл. с экрана. 
11. Ручин, В. А. Социальная безопасность российского общества в контексте социальной политики государства / В. А. Ручин // Вестник Саратовского государственного технического университета. -2011. - Т. 4, № 2 (60). - С. 322-326.

12. Система долговременного ухода за гражданами пожилого возраста. - Электрон. текстовые дан. - Режим доступа: http://uszn.volgograd.ru/other/ sistema-dolgovremennogo-ukhoda-za-grazhdanamipozhilogo-vozrasta/ (дата обращения: 12.09.2020).Загл. с экрана.

13. Социальная поддержка граждан // Портал госпрограмм РФ. - Электрон. текстовые дан. - Режим доступа: https://programs.gov.ru/Portal/ program/03/passport (дата обращения: 12.09.2020).Загл. с экрана.

14. Устинкин, С. В. Перестройка и гласность (об источниках формирования современной политической коммуникации власти и общества в России) / С. В. Устинкин, Л. Н. Ульмаева // Власть. - 2009. № 10. - С. 24-27.

15. Шкудунова, Ю. В. Публично-общественная сфера и политическое пространство / Ю. В. Шкудунова // Омский научный вестник. - 2010. - № 5 (91). C. $99-102$.

\section{REFERENCES}

1. Vladimir Putin poruchil izuchit opyt Volgogradskoi oblasti po sozdaniiu Sotsialnogo kodeksa [Vladimir Putin Instructed to Study the Experience of the Volgograd Region in the Creation of the Social Code]. URL: https://www.volgograd.ru/ gubernator/tekush/183141/ (accessed 12 September 2020).

2. Grigoreva I.A. Sotsialnaia politika: osnovnye poniatiia [Social Policy: Basic Concepts]. Zhurnal issledovanii sotsialnoi politiki [The Journal of Social Policy Studies], 2003, vol. 1, no. 1. URL: https:// cyberleninka.ru/article/n/sotsialnaya-politikaosnovnye-ponyatiya (accessed 10 September 2020).

3. Konstitutsiia Rossiiskoi Federatsii (priniata vsenarodnym golosovaniem 12.12.1993 s izmeneniiami, odobrennymi $v$ khode obshcherossiiskogo golosovaniia 01.07.2020) [The Constitution of the Russian Federation (Adopted by Popular Vote on 12.12.1993 With Amendments Approved During a Nationwide Vote on 01.07.2020)]. URL: http://kremlin.ru/acts/constitution (accessed 14 September 2020).

4. Morozov S.I., Poroshina T.V. Kommunikativnye tekhnologii legitimatsii regionalnykh organov ispolnitelnoi vlasti $\mathrm{v}$ Volgogradskoi oblasti [Communicative Technologies of the Regional Executive Authorities' Legitimation in the Volgograd Region].
Izvestiia Tulskogo gosudarstvennogo universiteta. Gumanitarnye nauki [Bulletin of Tula State University. Film Humanities], 2017, no. 1, pp. 55-61.

5. Morozov S.I., Pankratov S.A. Respublika Krym, Sevastopol i Volgogradskaia oblast: politicheskie strategii sotrudnichestva [The Republic of Crimea, Sevastopol and the Volgograd Region: Political Strategies for Cooperation]. Istoriia $i$ sovremennoe razvitie Prichernomoria v kontekste formirovaniia patriotizma i ukrepleniia tsennostei rossiiskoi tsivilizatsii: materialy Mezhdunarodnoy nauchno-prakticheskoy konferentsii [History and Today's Development of the Black Sea Region in the Context of the Formation of Patriotism and Strengthening of the Values of Russian Civilization. Proceedings of the International Research and Practice Conference]. Novorossiysk, Kuban State University, 2018, pp. 313-316.

6. Olson M. Logika kollektivnykh deistvii. Obshchestvennye blaga i teoriia grupp [The Logic of Collective Action: Public Goods and the Theory of Groups]. Moscow, FEI, 1995. 174 p.

7. Pankratov S.A. Sotsialno-politicheskoe proektirovanie publichnogo prostranstva Volgogradskoi oblasti [Socio-Political Design of the Public Space of the Volgograd Region]. Traektorii politicheskogo razvitiia Rossii: instituty, proekty, aktory: materialy Vserossiyskoy nauchnoy konferentsii RAPN s mezhdunarodnym uchastiem [Trajectories of Russia's Political Development: Institutions, Projects, Actors]. Moscow, Moscow State Pedagogical University, 2019, pp. 297-298.

8. Parsons T. Sotsialnaia Sistema [Social System]. Moscow, Akademicheskii proekt Publ., 2018. 530 p.

9. Rasporiazhenie Pravitelstva RF ot 06.09.2010 N 1485-r (red. ot 24.06.2020) «Ob utverzhdenii Strategii sotsialno-ekonomicheskogo razvitiia Severo-Kavkazskogo federalnogo okruga do 2025 goda» [Order of the Government of the Russian Federation of 06.09.2010 N 1485-r (as amended on 24.06.2020) "On Approval of the Strategy for the Socio-Economic Development of the North Caucasus Federal District until 2025"]. URL: http://www. consultant.ru/document/cons_doc_LAW_105643/ 517741733b081df06def6b33102ee7434eda031c/ (accessed 13 September 2020).

10. Rasporiazhenie Pravitelstva RF ot 5 sentiabria 2011 g. N 1538-r «O Strategii sotsialnoekonomicheskogo razvitiia Iuzhnogo federalnogo okruga na period do 2020 g." [Order of the Government of the Russian Federation of September 5, 2011 N 1538-r "On the Strategy of SocioEconomic Development of the Southern Federal District for the Period up to 2020"]. URL: http:// docs.cntd.ru/document/902301126 (accessed 13 September 2020). 


\section{ПРАКТИКИ ВЗАИМОДЕЙСТВИЯ ИНСТИТУТОВ ВЛАСТИ И ОБЩЕСТВА}

11. Ruchin V.A. Sotsialnaia bezopasnost rossiiskogo obshchestva v kontekste sotsialnoi politiki gosudarstva [Social Security of the Russian Society in the Context of the State Social Policy]. Vestnik Saratovskogo gosudarstvennogo tekhnicheskogo universiteta [Vestnik of the Saratov State Technical University], 2011, vol. 4, no. 2 (60), pp. 322-326.

12. Sistema dolgovremennogo ukhoda za grazhdanami pozhilogo vozrasta [Long-Term Care System for Senior Citizens]. URL: http://uszn. volgograd.ru/other/sistema-dolgovremennogoukhoda-za-grazhdanami-pozhilogo-vozrasta/ (accessed 12 September 2020).

13. Sotsialnaia podderzhka grazhdan [Social Support of Citizens]. Portal gosprogramm RF [Portal of State Programs of the Russian Federation]. URL: https://programs.gov.ru/Portal/program/03/passport (accessed 12 September 2020).

14. Ustinkin S.V., Ulmaeva L.N. Perestroika i glasnost (ob istochnikakh formirovaniia sovremennoi politicheskoi kommunikatsii vlasti i obshchestva v Rossii) [Perestroika and Glasnost (on the Sources of Modern Political Communication Between Government and Society in Russia)]. Vlast, 2009, no. 10, pp. 24-27.

15. Shkudunova Iu.V. Publichno-obshchestvennaia sfera i politicheskoe prostranstvo [The Public Sphere and Political Space]. Omskii nauchnyi vestnik [Omsk Scientific Bulletin], 2010, no. 5 (91), pp. 99-102.

\section{Information About the Authors}

Sergey D. Gavrilov, Senior Lecturer, Department of International Relations, Political Science and Area Studies, Volgograd State University, Prosp. Universitetsky, 100, 400062 Volgograd, Russian Federation, gavrilov_sd@volsu.ru,https://orcid.org/0000-0002-9098-8301

Diana K. Azizova, Postgraduate Student, Assistant, Department of International Relations, Political Science and Area Studies, Volgograd State University, Prosp. Universitetsky, 100, 400062 Volgograd, Russian Federation, azizova.dk@volsu.ru, https://orcid.org/0000-0001-8440-5969

\section{Информация об авторах}

Сергей Дмитриевич Гаврилов, старший преподаватель кафедры международных отношений, политологии и регионоведения, Волгоградский государственный университет, просп. Университетский, 100, 400062 г. Волгоград, Российская Федерация, gavrilov_sd@volsu.ru, https://orcid.org/0000-0002-9098-8301

Диана Качабековна Азизова, аспирант, ассистент кафедры международных отношений, политологии и регионоведения, Волгоградский государственный университет, просп. Университетский, 100, 400062 г. Волгоград, Российская Федерация, azizova.dk@volsu.ru, https:/orcid.org/0000-0001-8440-5969 